\title{
Induction of Tumor Necrosis Factor (TNF) Release from Subtypes of T Cells by Agonists of Proteinase Activated Receptors
}

\author{
Haiwei Yang, ${ }^{1}$ Tao Li, ${ }^{2}$ Jifu Wei, ${ }^{1}$ Huiyun Zhang, ${ }^{2}$ and Shaoheng $\mathrm{He}^{1,3}$ \\ ${ }^{1}$ Department of Urology, The First Affiliated Hospital of Nanjing Medical University, Nanjing, 300 Guangzhou Road, \\ Jiangsu 210029, China \\ ${ }^{2}$ Department of Infectious Diseases, The First Affiliated Hospital of Shantou University Medical College, Shantou 515041, China \\ ${ }^{3}$ Allergy and Clinical Immunology Research Centre, The First Affiliated Hospital of Liaoning Medical University, \\ Jinzhou, Liaoning 121001, China
}

Correspondence should be addressed to Shaoheng He; shoahenghe@hotmail.com

Received 2 July 2013; Revised 22 November 2013; Accepted 22 November 2013

Academic Editor: Mohammad Athar

Copyright (c) 2013 Haiwei Yang et al. This is an open access article distributed under the Creative Commons Attribution License, which permits unrestricted use, distribution, and reproduction in any medium, provided the original work is properly cited.

Serine proteinases have been recognized as playing an important role in inflammation via proteinase activated receptors (PARs). However, little is known about the influence of serine proteinases and PARs on TNF secretion from highly purified T cells. We challenged $\mathrm{T}$ cells from human peripheral blood with serine proteinases and agonist peptides of PARs and measured the levels of TNF in culture supernatants by ELISA. The results showed that thrombin and trypsin, but not tryptase, stimulated approximately up to 2.5-fold increase in TNF release from T cells following $16 \mathrm{~h}$ incubation. Proteinase inhibitors and PAR-1 antagonist SCH 79797 almost completely abolished thrombin- and trypsin-induced TNF release from T cells. Agonist peptides of PAR-1, but not PAR2 induced TNF release from T cells. Moreover, trypsin- and thrombin-induced upregulated expression of TNF was observed in CD4+, IL-4+, or CD25+ T cells, but not in IFN+ or IL-17+ T cells. The signaling pathways MAPK/ERK and PI3K/Akt are involved in the thrombin- and trypsin-induced TNF release from T cells. In conclusion, thrombin and trypsin can induce TNF release from IL-4+ and CD25+ T cells through activation of PAR-1 and therefore contribute to regulation of immune response and inflammation of the body.

\section{Introduction}

Proteinase-activated receptors (PARs) belong to a family of G-protein-coupled receptors with seven transmembrane domains activated via proteolytic cleavage by serine proteinases [1]. A total of four PARs have been identified and cloned. Among them, PAR-1 [2, 3], PAR-3 [4], and PAR-4 [5] are targets for thrombin, trypsin, and cathepsin G, whereas PAR-2 is resistant to thrombin but can be activated by trypsin, mast cell tryptase [6,7], neutrophil elastase [8], and insectderived proteinase [9].

PARs are expressed by various cells involved in inflammatory and immunological responses, such as vascular endothelial cells, epithelial cells, mast cells, T cells, monocyte, eosinophils, and neutrophils $[10,11]$. In these cells, activation of PARs affects their main functions such as proliferation, degranulation, and release of inflammatory mediators [10, 11]. In our previous study [12], we have showed the expression of PAR-1, PAR-2, and PAR-3 on T cells, and thrombin-, trypsin-, and tryptase-induced interleukin (IL-6) release from T cells. It has also been reported that cytoplasmic free calcium and phospholipase $\mathrm{C}$ and protein kinase $\mathrm{C}$ activation are increased in T-leukemic cell lines following stimulation with thrombin or the thrombin receptor agonist peptide [13]. Thrombin and thrombin receptor agonist also enhanced CD69 expression and IL-2 productions by cross-linking T cell receptors in both Jurkat $\mathrm{T}$ cells and peripheral blood lymphocytes [14]. We, therefore, anticipated that thrombin, trypsin, and tryptase might induce TNF release from T cells through PARs. 
TNF is a major proinflammatory cytokine that is thought to be important in the pathogenesis of asthma [15], food allergy [16], ocular allergy [17], and atopic dermatitis [18]. It has been reported that the increased number of TNF expressing cells and levels of TNF is observed in the bronchoalveolar lavage (BAL) and in the airways of asthmatics [19]. Inhaled TNF increases airway responsiveness to methacholine in asthmatic subjects associated with a sputum neutrophilia [20]. Since PARs, TNF, and T cells all play roles in inflammation, we believe, there must be some linkages between them. The aim of the present study is to investigate roles of thrombin, tryptase, trypsin, elastase, and agonist peptides of PARs in the secretion of TNF from purified human $T$ cells and subtypes of $\mathrm{T}$ cells.

\section{Materials and Methods}

2.1. Reagents. Human thrombin, trypsin (specific activity: $\sim 10,000$ BAEE U/mg protein), soybean trypsin inhibitor (SBTI), and bovine serum albumin (BSA, fraction V) were purchased from Sigma (St Louis, MO, USA). Recombinant hirudin and human neutrophil elastase (specific activity: $20 \mathrm{MeO}-S u c-A l a-A l a-P r o-V a l-p N A \mathrm{U} / \mathrm{mg}$ protein) were obtained from Calbiochem (San Diego, CA, USA). Recombinant human Lung $\beta$ tryptase (specific activity: $\sim 1,000 \mathrm{~N} \alpha$ CBZ-L-Lysine Thiobenzyl Ester U/mg protein) was from Promega (Madison, WI, USA). SCH 79797 was from Tocris Cookson (Ellisville, Mo, USA). Agonist peptides of PARs, and their reverse forms, and PAR-2 antagonist peptide FSLLRY- $\mathrm{NH}_{2}$ were synthesized in CL Bio-Scientific Inc. (Xi An, China). The sequences of the active and reverse peptides were PAR-1, SFLLR-NH $\mathrm{N}_{2}$ and RLLFS-NH $\mathrm{N}_{2}$, TFLLRN-NH $\mathrm{N}_{2}$ and NRLLFT-NH $\mathrm{N}_{2}$; PAR-2, SLIGKV-NH ${ }_{2}$ and VKGILS- $\mathrm{NH}_{2}$ as well as trans cinnamoyl (tc)-LIGRLO-NH$H_{2}$ and tc-OLRGIL-NH $\mathrm{N}_{2}$; PAR-3, TFRGAP$\mathrm{NH}_{2}$ and PAGRFT-NH $\mathrm{N}_{2}$. RPMI 1640 and newborn calf serum (NCS) were obtained from GIBCO (Carlsbad, CA, USA). Ficoll-Paque Plus was from Amersham Biosciences (Uppsala, Sweden). PE-conjugated mouse anti-human CD3 monoclonal antibody, PE-conjugated goat-anti rabbit IgG, and TNF OptEIA ELISA kits were purchased from BD PharMingen (San Jose, CA, USA). TRIzol reagent and SYBR Green I Stain were purchased from Invitrogen (Carlsbad, CA, USA). Cellular activation of signaling kits for extracellular signal-regulated kinase (ERK), 2-(2-diamino)3-methoxyphenyl-4H-1-benzopyran-4-one (PD98059), Akt, PI3K, and P38 2-(4-morpholinyl)-8-phenyl-4H-1benzopyran-4-one (LY294002) was purchased from Cell Signaling Technology (Beverly, MA, USA). ExScript RT reagent kit and SYBR Premix Ex Taq (perfect real time) were obtained from TaKaRa (DaLian, China). Rabbit anti-human PAR-1 and rabbit anti-huamn PAR-2 polyclonal antibodies were purchased from Santa Cruz Biotechnology (Santa Cruz, CA, USA). FITC-conjugated mouse anti-human CD4 monoclonal, PE-conjugated mouse anti-human CD8 monoclonal, Percp-cy5.5-conjugated mouse anti-human TNF monoclonal, FITC-conjugated mouse anti-human IFN monoclonal, PE-conjugated mouse anti-human IL-4 monoclonal, APC-conjugated mouse anti-human CD25 monoclonal, and APC-conjugated mouse anti-human IL-17 monoclonal antibodies were purchased from eBioscience. Lymphocyte Isolation Kit I was from Miltenyi Biotec (Bergisch Gladbach, Germany). All other reagents were of analytic grade and obtained from Sigma (St Louis, MO, USA).

2.2. Isolation and Culture of $T$ Cells. Human $\mathrm{T}$ cells were isolated from peripheral blood mononuclear cells (PBMCs) by a MACS system with T Cell Isolation Kit I according to the manufacturer's protocol. In brief, PBMCs were isolated from fresh blood donated by healthy volunteers, $100 \mathrm{~mL}$ from each individual per visit. The informed consent from each volunteer and agreement with the ethical committee of the First Affiliated Hospital of Nanjing Medical University were obtained. After being separated from red blood cells by FicollPaque density gradient, PBMCs were collected and incubated with microbead-linked anti-CD3 monoclonal antibody for $15 \mathrm{~min}$ at $8^{\circ} \mathrm{C}$. CD3 + T cells were separated from other cells by passing through a magnetic cell separation system. For purity analysis, the cells were resuspended in PBS and incubated with PE-conjugated monoclonal antibody against human CD3 for $1 \mathrm{~h}$. The purity of T cells was consistently more than $95 \%$ and cell viability was more than $98 \%$. The purified CD3+ $\mathrm{T}$ cells were then used for the further cell challenge tests.

2.3. Purified T-Cell Challenge. T cells were cultured in 24-well culture plates at a density of $5 \times 10^{5}$ cells/well in RPMI 1640 medium containing $10 \% \mathrm{NCS}$ at $37^{\circ} \mathrm{C}$ for $2 \mathrm{~h}$ with $5 \% \mathrm{CO}_{2}$, respectively. The culture supernatants were then removed and cells were washed twice with fresh serum-free RPMI 1640 medium at $300 \mathrm{~g}$ for $10 \mathrm{~min}$. For challenge experiments, cells were exposed to various doses of thrombin (0.01$3.0 \mu \mathrm{g} / \mathrm{mL}, 1 \mathrm{U}=0.5 \mu \mathrm{g}, 1 \mathrm{U} / \mathrm{mL}=5.6 \mathrm{nM}, \mathrm{U}=\mathrm{NIH}$ unit), trypsin $(0.01-0.3 \mu \mathrm{g} / \mathrm{mL}, 1 \mu \mathrm{g} / \mathrm{mL}=42 \mathrm{nM})$, tryptase $(0.25-$ $2.0 \mu \mathrm{g} / \mathrm{mL}, 1 \mu \mathrm{g} / \mathrm{mL}=7.4 \mathrm{nM})$, and elastase $(0.01-0.3 \mu \mathrm{g} / \mathrm{mL}$, $1 \mu \mathrm{g} / \mathrm{mL}=34 \mathrm{nM}, 1 \mathrm{U} / \mathrm{mL}=1700 \mathrm{nM}$ ) with or without their inhibitors; and to agonist peptides of PAR-1, PAR-2 and PAR3 (all at $0.1-100 \mu \mathrm{M}$ ) and their reverse peptides, respectively, for $16 \mathrm{~h}$ before the culture, supernatants were harvested and stored at $-40^{\circ} \mathrm{C}$ till use. The cell pellet was used for flow cytometry analysis.

2.4. Real-Time PCR Analysis of TNF Gene Expression in Purified T Cells. Quantitative expression of TNF mRNAs in $\mathrm{T}$ cells was determined by real-time PCR following the manufacture's protocol. Briefly, after synthesizing cDNA from the total RNA by using ExScriptTM RT reagent kit, realtime PCR was performed by using SYBR Premix Ex Taq on the ABI Prism 7000 Sequence Detection System (Perkin Elmer Applied Systems, Foster City, CA, USA). Each reaction contains $12.5 \mu \mathrm{L}$ of $2 \times$ SYBR green Master Mix, $1 \mu \mathrm{L}$ of $10 \mu \mathrm{M}$ of primers, $1 \mu \mathrm{L}$ of the cDNA, to a total volume of $25 \mu \mathrm{L}$. The thermal cycling conditions included an initial denaturation step at $50^{\circ} \mathrm{C}$ for $2 \mathrm{~min}, 95^{\circ} \mathrm{C}$ for $10 \mathrm{~min} ; 40$ cycles at $95^{\circ} \mathrm{C}$ for $15 \mathrm{~s}$, annealing temperatures at $60^{\circ} \mathrm{C}$ for $30 \mathrm{~s}$, and extension at $72^{\circ} \mathrm{C}$ for $30 \mathrm{~s}$. 
The sequences of PCR primers for TNF and $\beta$-actin were $5^{\prime}$-CCCCAGGGACCTCTCTCTAATC-3' (forward) and $5^{\prime}$-GGTTTGCTACAACATGGGCTACA-3' (reverse); $5^{\prime}$-AGGGGCCGGACTCGTCATACT- $3^{\prime}$ (forward), and $5^{\prime}$-GGCGGCAACACCATGTACCCT-3' (reverse), respectively.

Consequently, at the end of the PCR cycles, specificities of the amplification products were controlled by dissociation curve analysis. Expression of mRNA in each sample was finally determined after correction with $\beta$-actin expression. The gene specific threshold cycle $(\mathrm{Ct})$ for each sample $(\Delta \mathrm{Ct})$ was corrected by subtracting the $\mathrm{Ct}$ for the housekeeping gene $\beta$-actin. Untreated controls were chosen as the reference samples, and the $\Delta \mathrm{Ct}$ for all experimental samples was subtracted by the $\Delta \mathrm{Ct}$ for the control samples $(\Delta \Delta \mathrm{Ct})$. The magnitude change of test gene mRNA was expressed as $2-$ $\Delta \Delta$ Ct. Each measurement of a sample was conducted in duplicate.

\subsection{Western Blot Analysis of Signal Transduction Pathways} in Purified T Cells. T cells were preincubated with $50 \mu \mathrm{M}$ of PD98059, $20 \mu \mathrm{M}$ of LY294002, or medium alone for $30 \mathrm{~min}$ before adding thrombin $3.0 \mu \mathrm{g} / \mathrm{mL}$, trypsin $0.3 \mu \mathrm{g} / \mathrm{mL}$, or medium alone for $30 \mathrm{~min}, 2 \mathrm{~h}$, or $6 \mathrm{~h}$. The cells were lysed in a buffer containing $20 \mathrm{mM}$ of Tris- $\mathrm{HCl}(\mathrm{pH} 7.4), 137 \mathrm{mM}$ of $\mathrm{NaCl}, 10 \%$ glycerol, $1 \%$ Triton X-100, 2 mM of EDTA, $25 \mathrm{mM}$ of $\beta$-glycerophosphate, $2 \mathrm{mM}$ of sodium pyrophosphate, and $0.5 \mathrm{mM}$ of dithiothreitol at $4^{\circ} \mathrm{C}$ for $30 \mathrm{~min}$. Cell debris was removed by centrifugation of the lysate at $12,000 \times \mathrm{g}$ for $10 \mathrm{~min}$. The supernatants were mixed with equal volumes of 2x sodium dodecyl sulphate (SDS) sample buffer and heated to $100^{\circ} \mathrm{C}$ for $10 \mathrm{~min}$. An equal volume of sample was fractionated by SDS-PAGE on a $10 \%$ acrylamide gel and transferred onto polyvinylidene difluoride (PVDF) membranes with a Bio-Rad transfer system, according to the manufacturer's instructions. After blocking nonspecific binding sites with $5 \%$ BSA in TBST $(50 \mathrm{mM}$ of Tris, $0.15 \mathrm{M}$ of $\mathrm{NaCl}, 0.1 \%$ Tween 20, pH 7.6) for $1 \mathrm{~h}$, membranes were probed with phospho-ERK1/2, phospho-Akt, phospho-p38, or phosphoPI3k antibodies at $4^{\circ} \mathrm{C}$ overnight, followed by incubation with HRP-conjugated secondary antibodies. Immunoreactive bands were visualized by using enhanced chemiluminescence reagents according to the manufacturer's protocol. Densitometry analysis of immunoblots was carried out using Quantity One software (Bio-Rad, USA).

2.6. Determination of Cytokines. The levels of TNF in culture supernatants were measured with OptEIA ELISA kits according to the manufacturer's instructions. The plates were read on a plate reader (Molecular Devices, Menlo Park, CA) with the Softmax data analysis program. The minimum detectable concentration of TNF was $2.2 \mathrm{pg} / \mathrm{mL}$.

2.7. Flow Cytometry Analysis. To test the PAR1 and 2 expressions after treatment of trypsin and thrombin, isolated $\mathrm{T}$ cells were pelleted by centrifugation at $450 \mathrm{~g}$ for $10 \mathrm{~min}$ after cells were stimulated with thrombin $3.0 \mu \mathrm{g} / \mathrm{mL}$, trypsin $0.3 \mu \mathrm{g} / \mathrm{mL}$, or medium alone for $16 \mathrm{~h}$. For PAR1 and PAR2 staining, cells were incubated with rabbit anti-human PAR1 or PAR2 antibodies at $37^{\circ} \mathrm{C}$ for $1 \mathrm{~h}$. After washing, cells were incubated with $\mathrm{PE}$-conjugated goat anti-rabbit IgG antibody $37^{\circ} \mathrm{C}$ for $45 \mathrm{~min}$. After washing, cells were analyzed on a fluorescence-activated cell sorting (FACS) arial flow cytometer with CellDevia software (BD Biosciences, USA).

To test the secretion of TNF from subtypes of T cells, isolated $\mathrm{T}$ cells were pelleted by centrifugation at $450 \mathrm{~g}$ for $10 \mathrm{~min}$ and then fixed and permeabilized by using a cell fixation/permeabilization kit (BD Pharmingen). Briefly, thoroughly resuspended cells were added in $100 \mu \mathrm{L}$ of $\mathrm{BD}$ Cytofix/Cytoperm solution and incubated for $20 \mathrm{~min}$ at $4^{\circ} \mathrm{C}$. Cells were then incubated with fluorescence labeled anti-human CD4, CD8, CD25, TNF, IFN, IL-4, and IL-17 monoclonal antibodies or isotope control, respectively (at a final concentration of $4 \mu \mathrm{g} / \mathrm{mL}$ ) at $4^{\circ} \mathrm{C}$ for $30 \mathrm{~min}$. After washing, cells were analyzed on a fluorescence-activated cell sorting (FACS) Arial flow cytometer with CellDevia software (BD Biosciences, USA).

2.8. Statistical Analysis. The results were shown as mean \pm SEM. Differences between groups were tested for significance using the Student's $t$-test. $P<0.05$ was taken as statistically significant. All statistics were performed with SPSS 13.0 for window (SPSS Inc., Chicago, IL, USA).

\section{Results}

3.1. Induction of TNF Release from Purified T Cells by Serine Proteinases. The purity of $\mathrm{T}$ cells was consistently more than 95\% (date was shown in Supplementary Material, Figure S1). It has been shown that thrombin, trypsin, and tryptase can induce proinflammatory cytokine IL- 6 release from T cells [12], but little is known of serine proteinase-induced TNF release from $\mathrm{T}$ cells. Here, we showed that thrombin at concentrations of 1.0 and $3.0 \mu \mathrm{g} / \mathrm{mL}$ provoked TNF release from $\mathrm{T}$ cells following $16 \mathrm{~h}$ incubation period in a dose-dependent manner. Approximately up to 2.5 -fold increase in TNF release was observed when $T$ cells were incubated with thrombin for $16 \mathrm{~h}$. At $6 \mathrm{~h}$ following incubation, data (not shown) on both basal and induced TNF release from $\mathrm{T}$ cells were inconsistent. This is most likely due to the limitation of the assay sensitivity and relatively low secretion of TNF. PAR-1 agonist peptides, SFLLR- $\mathrm{NH}_{2}$ at the concentration of $100 \mu \mathrm{M}$ and TFLLRN$\mathrm{NH}_{2}$ at the concentration of $5 \mu \mathrm{M}$, induced a significant release of TNF at $16 \mathrm{~h}$ following incubation. However, RLLFS$\mathrm{NH}_{2}$, a reverse peptide of SFLLR- $\mathrm{NH}_{2}$, and NRLLFT- $\mathrm{NH}_{2}$, a reverse peptide of TFLLRN-NH${ }_{2}$, had little effect on release of TNF from T cells (Figure 1(a)).

Hirudin, a specific thrombin inhibitor, was able to inhibit thrombin-induced secretion of TNF. Approximately up to $82.4 \%$ inhibition of thrombin-induced secretion of TNF was observed when $3.0 \mu \mathrm{g} / \mathrm{mL}$ of thrombin and $10 \mathrm{U} / \mathrm{mL}$ of hirudin were added to $\mathrm{T}$ cells for $16 \mathrm{~h}$. Hirudin alone at the concentrations tested had little effect on TNF secretion from T cells. SCH 79797, a PAR-1 antagonist at the concentration of $1 \mu \mathrm{M}$, inhibited $89 \%$ thrombin-induced TNF release from $\mathrm{T}$ cells (Figure 1(a)). 


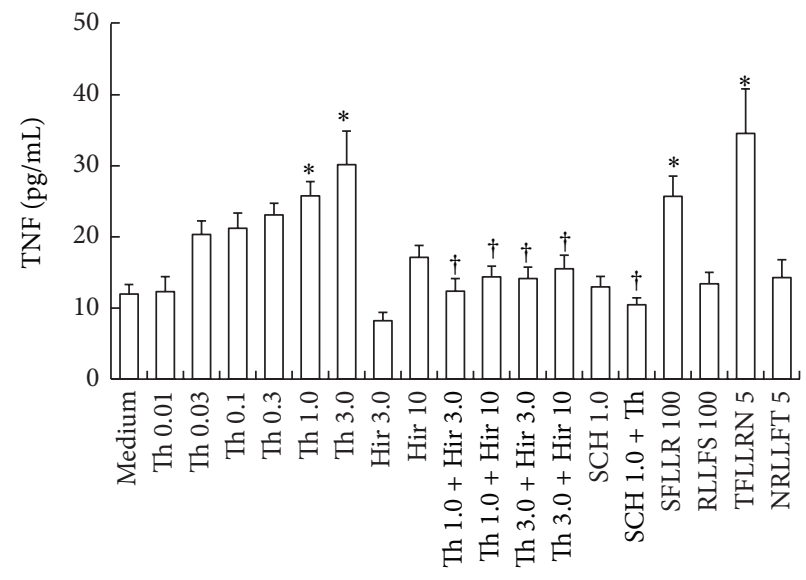

(a)

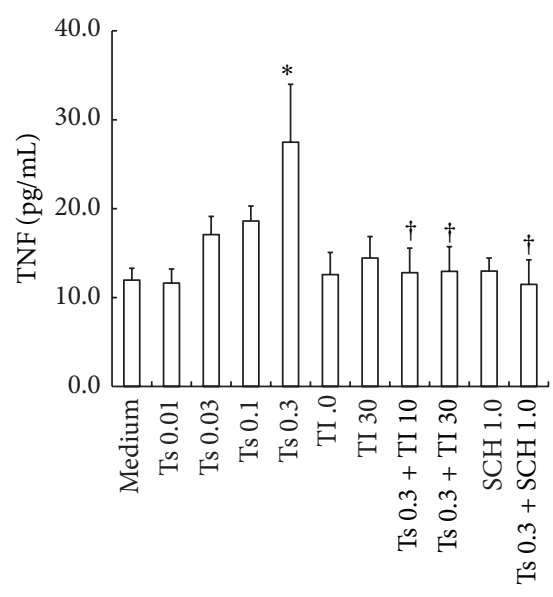

(b)

FIGURE 1: Induction of TNF secretion from human purified T cells by thrombin and trypsin. Cells were incubated with (a) various concentrations of thrombin (Th, $\mu \mathrm{g} / \mathrm{mL})$, SFLLR $(\mu \mathrm{M})$, TFLLRN $(\mu \mathrm{M})$, and their reverse peptides RLLFS $(\mu \mathrm{M})$, NRLLFT $(\mu \mathrm{M})$, and $(\mathrm{b})$ $\operatorname{trypsin}(\mathrm{Ts}, \mu \mathrm{g} / \mathrm{mL})$ in the presence or absence of their inhibitors, respectively, for $16 \mathrm{~h}$ at $37^{\circ} \mathrm{C}$. Values shown are mean \pm SEM for four to six independent experiments from different donors. ${ }^{*} P<0.05$ compared with the response to medium alone control. ${ }^{\dagger} P<0.05$ compared with the response to the corresponding proteinase alone. Hir $=$ hirudin $(\mathrm{U} / \mathrm{mL}), \mathrm{TI}=\mathrm{SBTI}(\mu \mathrm{g} / \mathrm{mL})$, and SCH $=\mathrm{SCH} 79797(\mu \mathrm{M})$.

Similarly, trypsin at the concentration of $0.3 \mu \mathrm{g} / \mathrm{mL}$ induced 2.3-fold increase in TNF release from $\mathrm{T}$ cells at $16 \mathrm{~h}$ (Figure 1(b)). However, tryptase at the concentrations up to $2 \mu \mathrm{g} / \mathrm{mL}$ and elastase at the concentrations up to $6 \mathrm{U} / \mathrm{mL}$ had little effect on TNF release from T cells (data not shown). Inhibitors of trypsin, SBTI at the concentrations of 10 and $30 \mu \mathrm{g} / \mathrm{mL}$, eliminated $0.3 \mu \mathrm{g} / \mathrm{mL}$ trypsin-induced TNF release by a value up to 94.8 and $94.2 \%$, respectively. SBTI alone at the concentrations tested had little effect on TNF secretion from T cells. SCH 79797, a PAR-1 antagonist at the concentration of $1 \mu \mathrm{M}$, inhibited $96.8 \%$ trypsin-induced TNF release from T cells (Figure 1(b)).

SLIGKV, an agonist peptide of PAR-2 and TFRGAP- $\mathrm{NH}_{2}$, an agonist peptide of PAR-3 at the concentrations up to $100 \mu \mathrm{M}$, did not appear to have any effect on TNF release from $\mathrm{T}$ cells (data not shown).

\subsection{Real-Time PCR Analysis of Expression of TNF $m R N A$} in Purified T Cells. In order to confirm the findings above, we investigated the influence of the serine proteinases on the expression of TNF mRNA in T cells. It was found that the expression of TNF mRNA was upregulated when $\mathrm{T}$ cells were incubated with thrombin at 1 and $3 \mu \mathrm{g} / \mathrm{mL}$ for 2 and $6 \mathrm{~h}$. The maximum enhanced expression of TNF mRNA was 4.2-fold over baseline control (Figure 2(a)) after $6 \mathrm{~h}$ incubation. Hirudin, a specific thrombin inhibitor at the concentration of $3 \mathrm{U} / \mathrm{mL}$, completely abolished thrombininduced upregulated expression of TNF mRNA after $6 \mathrm{~h}$ incubation (Figure 2(b)).

Trypsin at the concentration of $0.3 \mu \mathrm{g} / \mathrm{mL}$ also induced increased expression of TNF mRNA by a value up to approximately 4.0-fold in T cells (Figure 2(a)), which was completely blocked by SBTI (Figure 2(b)). Similarly, SCH 79797 at the concentration of $1 \mu \mathrm{M}$ inhibited both thrombin- and trypsininduced upregulated expression of TNF mRNA in T cells by a value up to 72 and $72.5 \%$, respectively (Figure 2(b)).

SFLLR- $\mathrm{NH}_{2}$ at the concentration of $100 \mu \mathrm{M}$ and TFLLRN- $\mathrm{NH}_{2}$ at the concentration of $5 \mu \mathrm{M}$ significantly increase the expression of TNF mRNA at 2 and $6 \mathrm{~h}$ following incubation (Figure 2(a)). But RLLFS- $\mathrm{NH}_{2}$, a reverse peptide of SFLLR-NH $\mathrm{N}_{2}$, and NRLLFT-NH $\mathrm{N}_{2}$, a reverse peptide of TFLLRN-NH ${ }_{2}$, had little effect on expression of TNF mRNA in $\mathrm{T}$ cells (data not shown).

At the same time, neither thrombin nor trypsin showed obvious effect on the expression of PAR-1 and PAR-2 (data not shown).

3.3. Upregulated Expression of TNF in Subtypes of T Cells. It is wellknown that there are numerous subtypes of $\mathrm{T}$ cells and each of them has distinctive functions. We, therefore, investigated subtypes of $\mathrm{T}$ cells by flow cytometer analysis in order to determine the subtypes that upregulate TNF in response to trypsin or thrombin. The results showed that trypsin and thrombin induced upregulated expression of TNF in CD4+ T cells, but not CD8 $+\mathrm{T}$ cells, following $16 \mathrm{~h}$ incubation period. Among CD4+ T cells, trypsin and thrombin enhanced TNF expression in IL-4+ or CD25+ T cells, but not in IFN+ or IL-17+ T cells. SCH 79797 was able to inhibit enhanced TNF expression induced by trypsin and thrombin (Figures 3(a) and 3(b)).

3.4. Effect of PD98059 and LY294002 on Release and Gene Expression of TNF. In order to examine signal transduction pathways of thrombin and trypsin, $T$ cells were preincubated with PD98059, LY294002, or medium alone for $30 \mathrm{~min}$ before adding thrombin $3.0 \mu \mathrm{g} / \mathrm{mL}$, trypsin $0.3 \mu \mathrm{g} / \mathrm{mL}$, or medium 


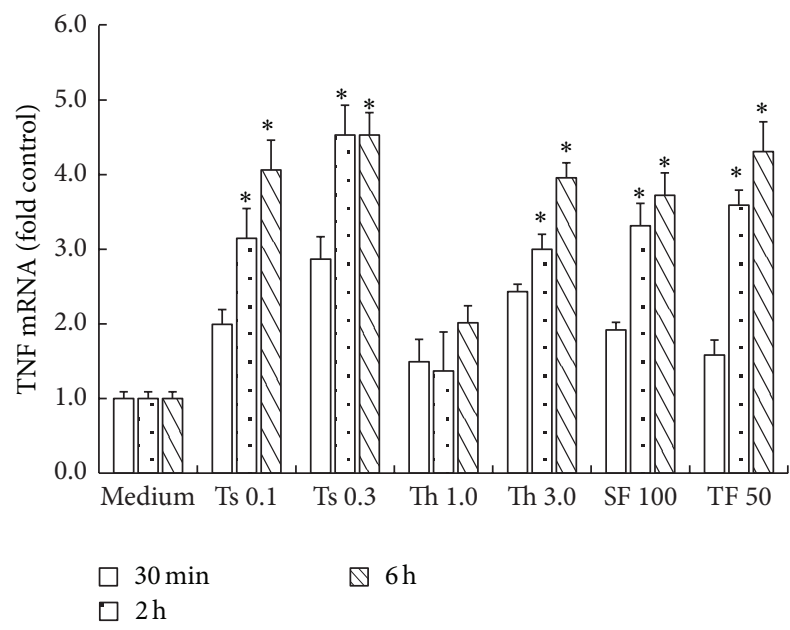

(a)

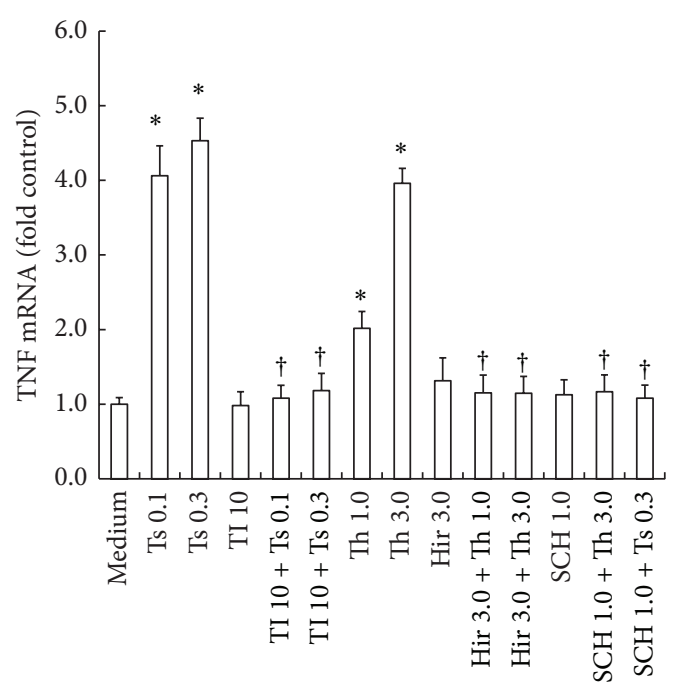

(b)

Figure 2: Induction of upregulated expression of TNF mRNA in purified T cells by thrombin and trypsin. (a) Cells were incubated with various concentrations of thrombin $\left(\mathrm{Th}, \mu \mathrm{g} / \mathrm{mL}\right.$ ), trypsin $\left(\mathrm{Ts}, \mu \mathrm{g} / \mathrm{mL}\right.$ ), SFLLR- $\mathrm{NH}_{2}$ (SF, $\mu \mathrm{M}$ ), and TFLLRN-NH 2 (TF, $\left.\mu \mathrm{M}\right)$ for $30 \mathrm{~min}, 2 \mathrm{~h}$ or $6 \mathrm{~h}$ at $37^{\circ} \mathrm{C}$. (b) Cells were incubated with $\mathrm{Th}(\mu \mathrm{g} / \mathrm{mL})$ and $\mathrm{Ts}(\mu \mathrm{g} / \mathrm{mL})$ in the presence or absence of their inhibitors, respectively for $6 \mathrm{~h}$ at $37^{\circ} \mathrm{C}$. Values shown are mean \pm SEM for four to six independent experiments from different donors. ${ }^{*} P<0.05$ compared with the response to medium alone control. ${ }^{\dagger} \mathrm{P}<0.05$ compared with the response to the corresponding proteinase alone. Hir $=\mathrm{hirudin}(\mathrm{U} / \mathrm{mL})$, TI $=\mathrm{SBTI}$ $(\mu \mathrm{g} / \mathrm{mL})$, and SCH $=\mathrm{SCH} 79797(\mu \mathrm{M})$.

alone for $16 \mathrm{~h}$. Following $16 \mathrm{~h}$ incubation period, PD98059 an inhibitor of MAPK pathway, and LY294002, an inhibitor of PI3K, completely blocked thrombin- and trypsin-induced release of TNF (Figure 4(a)).

Furthermore, PD98059 inhibited thrombin- and trypsininduced upregulation of expression of TNF mRNA by a value up to 91.2 and $98.6 \%$, and LY294002 eliminated thrombinand trypsin-induced expression of TNF mRNA by 95.5 and $83.2 \%$ in $\mathrm{T}$ cells following $6 \mathrm{~h}$ incubation (Figure 4(b)).

3.5. Effect of PD98059 on Phosphorylation of ERK in Purified T Cells. Thrombin $(3 \mu \mathrm{g} / \mathrm{mL})$ and trypsin- $(0.3 \mu \mathrm{g} / \mathrm{mL})$ induced enhanced phosphorylation of ERK1/2 in T cells following $0.5,2$, and $6 \mathrm{~h}$ incubation periods. However, thrombin and trypsin did not significantly affect phosphorylation of P38 in T cells following $0.5,2$, and $6 \mathrm{~h}$ incubation periods (Date was shown in Supplementary Material, Figure S2). PD98059 was able to completely block thrombin- and trypsin-induced phosphorylation of ERK1/2 when it was preincubated with T cells for $30 \mathrm{~min}$. PD98059 also inhibited basal phosphorylation of ERK1/2 in T cells (Figure 5).

3.6. Effect of LY294002 on Akt Phosphorylation in Purified T Cells. Thrombin at a concentration of $3 \mu \mathrm{g} / \mathrm{mL}$ and trypsin at a concentration of $0.3 \mu \mathrm{g} / \mathrm{mL}$ induced significantly increased phosphorylation of Akt in $\mathrm{T}$ cells following 0.5, 2, and $6 \mathrm{~h}$ incubation periods. However, thrombin and trypsin did not significantly affect phosphorylation of PI3k in $\mathrm{T}$ cells following $0.5,2$, and $6 \mathrm{~h}$ incubation periods (date was shown in Supplementary Material, Figure S3). LY294002 was able to block thrombin- and trypsin-induced phosphorylation of
Akt when it was incubated with T cells for $30 \mathrm{~min}$. LY294002 also diminished basal phosphorylation of Akt in T cells (Figure 6).

\section{Discussion}

We discovered in the present study that serine proteinases thrombin and trypsin, but not tryptase induced TNF release from human T cells. Since TNF is a potent proinflammatory cytokine, our observation is likely to add some novel information for, understanding of actions of serine proteinases in causing inflammation.

As little as $1.0 \mu \mathrm{g} / \mathrm{mL}$ of thrombin was able to induce significant TNF release from $\mathrm{T}$ cells, suggesting this proteinase is a potent secretagogue of TNF. This concentration of thrombin should be easily achieved in blood, particularly when the processes of platelet aggregation and coagulation are initiated [21]. Inhibition of thrombin-induced TNF release by a specific inhibitor of thrombin and hirudin indicates that action of thrombin on $\mathrm{T}$ cells was dependent on the enzymatic activity of this serine proteinase. There are 3 receptors for thrombin on cells, including PAR-1, PAR-3, and PAR-4 $[2,3]$. Since PAR-1 agonist peptides SFLLR-NH2, and TFLLRNNH2, but not PAR-3 agonist peptide TFRGAP-NH2 were capable of stimulating TNF release, a PAR-1 antagonist SCH 79797 [22] almost completely abolished thrombin-induced TNF release from $\mathrm{T}$ cells, and purified human $\mathrm{T}$ cells do not express PAR-4; the action of thrombin on $\mathrm{T}$ cells is most likely through activation of PAR-1. Our previous report which found thrombin-induced IL-6 secretion from human peripheral blood $\mathrm{T}$ cells may support our current findings [16]. 

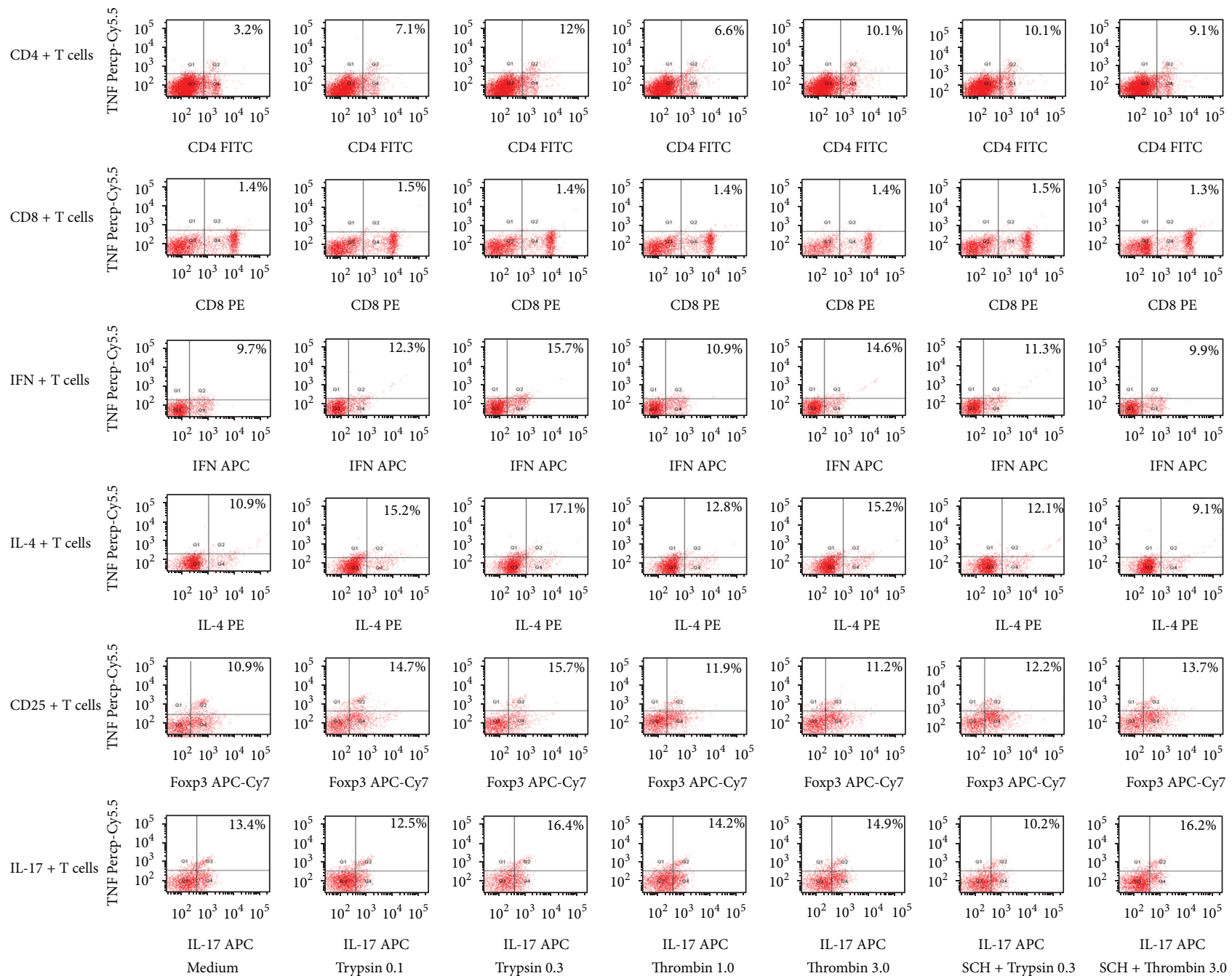

CD4 FITC

CD4 FITC

CD4 FITC
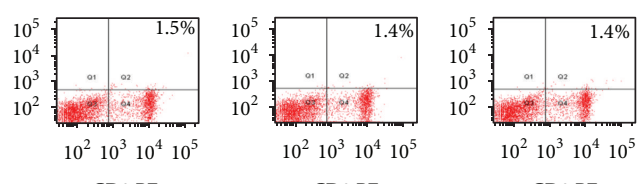

CD4 FITC

CD4 FITC

CD4 FITC
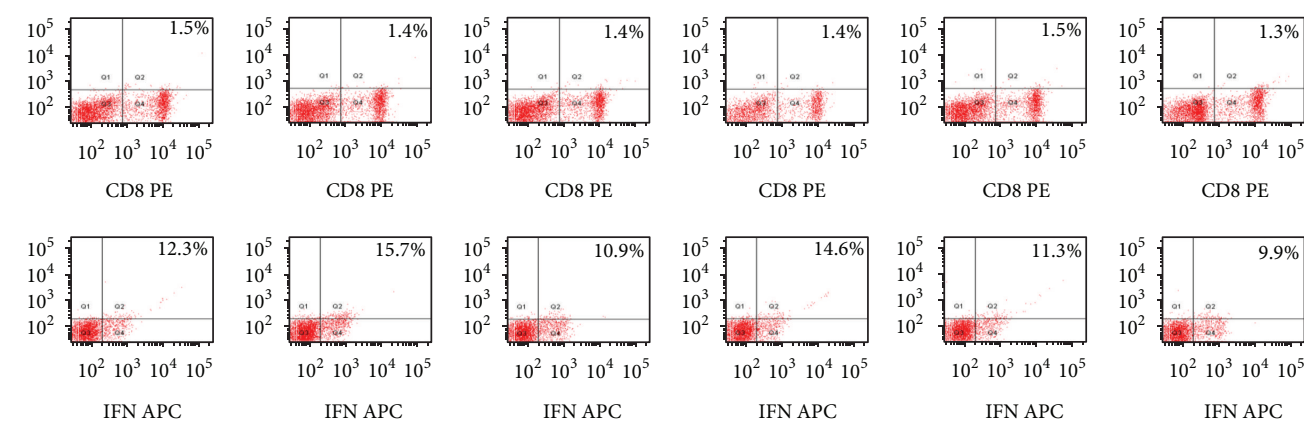

CD8 PE

CD8 PE
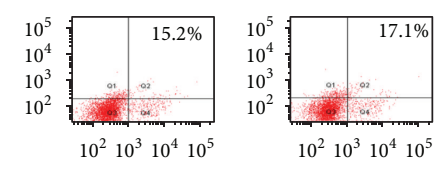

IFN APC
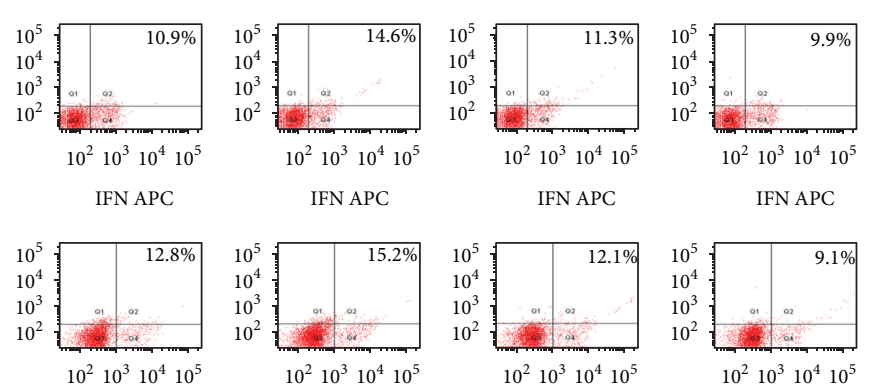

IL-4 PE
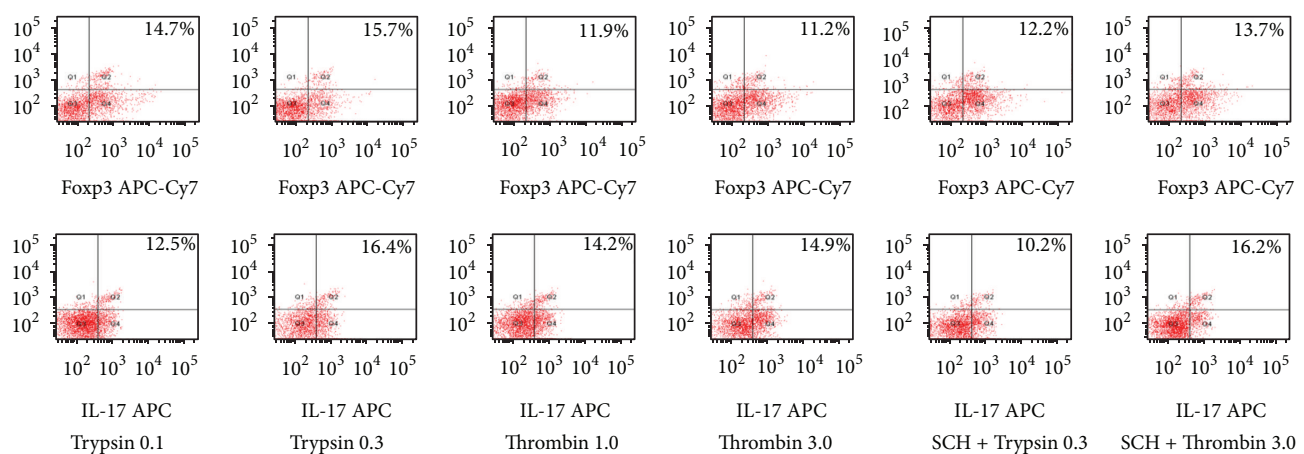

(a)

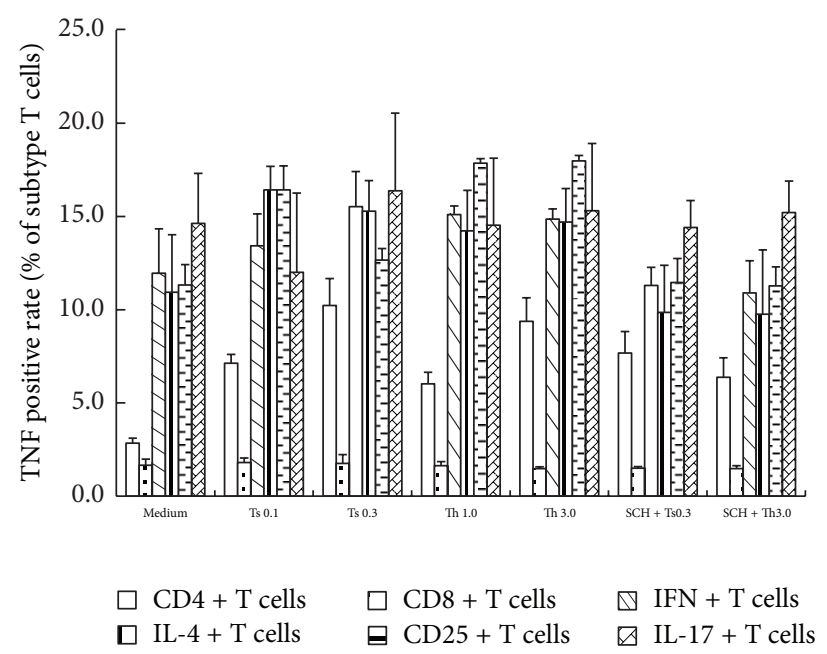

(b)

FIGURE 3: Induction of upregulated expression of TNF in subtypes of purified T cells. Isolated T cells were incubated with trypsin or thrombin for $16 \mathrm{~h}$ at $37^{\circ} \mathrm{C}$ before being analyzed by flow cytometer. (a) Numbers within the large gated regions indicate the percentage of TNF expression cells among different subtypes of T cells. (b) The mean \pm SEM data represented the percentage of TNF + cells in different subtypes of T cells indicated for four separate experiments. ${ }^{*} P<0.05$ in comparison with medium alone control. ${ }^{\dagger} P<0.05$ compared with the response to the corresponding uninhibited control. 


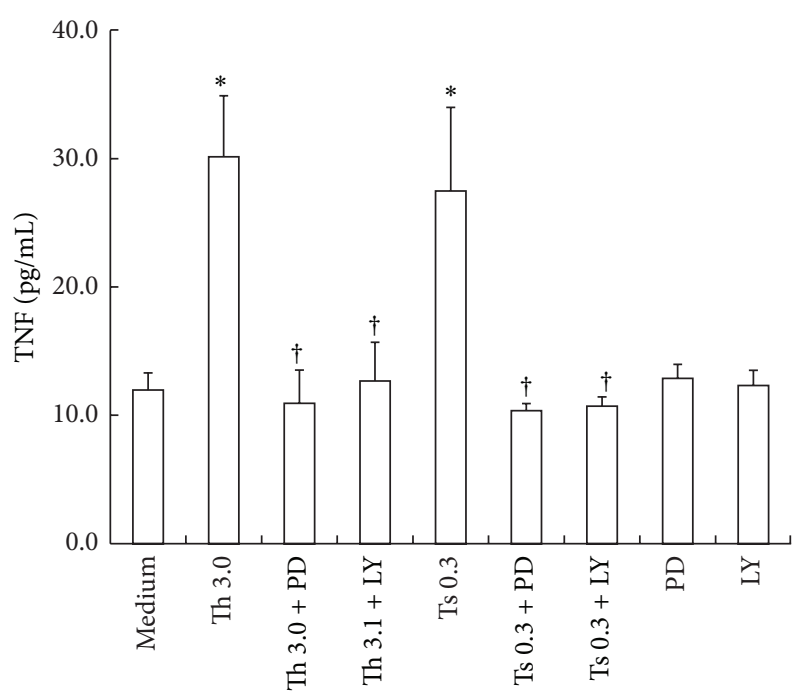

(a)

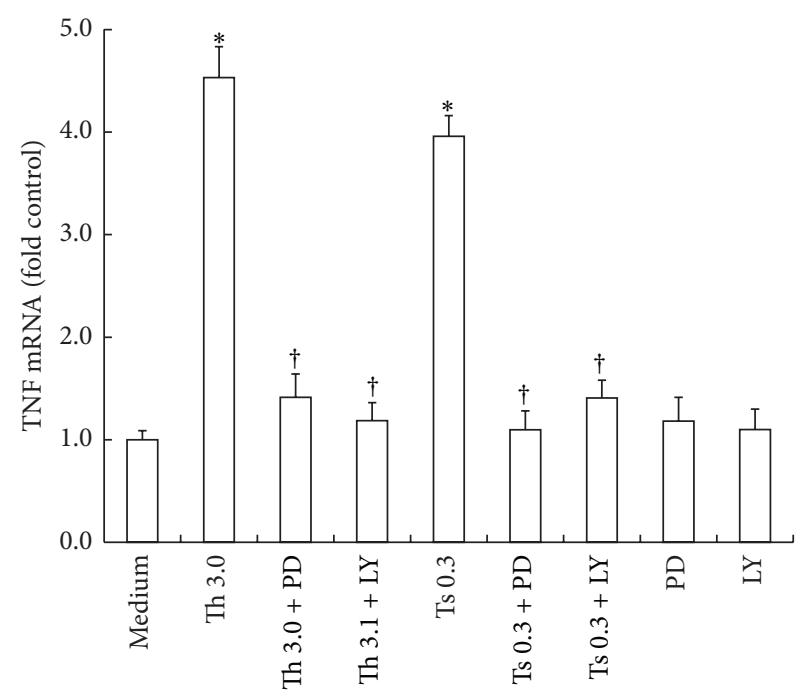

(b)

FIGURE 4: Effect of PD98059 and LY294002 on release and gene expression of TNF in purified T cells. PD98059 (PD, $50 \mu \mathrm{M})$ or LY294002 (LY, $20 \mu \mathrm{M}$ ) was preincubated with T cells at $37^{\circ} \mathrm{C}$ for $30 \mathrm{~min}$ before $3.0 \mu \mathrm{g} / \mathrm{mL}$ of thrombin and $0.3 \mu \mathrm{g} / \mathrm{mL}$ of trypsin being added for 6 or $16 \mathrm{~h}$. (a) Cells were collected for analysis of TNF release from T cells at $16 \mathrm{~h}$ following incubation. (b) Cells were collected for analysis of gene expression of TNF in T cells at $6 \mathrm{~h}$ following incubation. Values shown are mean \pm SEM for four to six independent experiments from different donors. ${ }^{*} P<0.05$ compared with the response to medium alone control. ${ }^{\dagger} P<0.05$ compared with the response to the corresponding proteinase alone. $\mathrm{Th}=$ thrombin $(\mu \mathrm{g} / \mathrm{mL}), \mathrm{Ts}=\operatorname{trypsin}(\mu \mathrm{g} / \mathrm{mL}), \mathrm{LY}=\mathrm{LY} 294002(\mu \mathrm{M})$, and PD = PD98059 $(\mu \mathrm{M})$.

While little information is available on induction of TNF release from $\mathrm{T}$ cells by trypsin, the ability of trypsin to stimulate IL-6 secretion from T cells [16] may support the anticipation that trypsin is capable of inducing cytokine release from T cells. As little as $0.3 \mu \mathrm{g} / \mathrm{mL}$ of trypsin was able to provoke TNF secretion from $\mathrm{T}$ cells proved that it is a potent stimulus of TNF release. As for thrombin, inhibitor of trypsin SBTI was able to inhibit trypsin-induced TNF release from $\mathrm{T}$ cells, indicating that an intact catalytic site is required for the serine proteinase to stimulate TNF release. Since PAR-1 is one of three receptors of trypsin, PAR-1 agonist peptides SFLLR-NH $\mathrm{N}_{2}$ and TFLLRN-NH $\mathrm{N}_{2}$ are capable of stimulating TNF release from T cells, and SCH 79797 almost completely abolished trypsin-induced TNF release from $\mathrm{T}$ cells, the action of trypsin on $\mathrm{T}$ cells is most likely through activation of PAR-1. PAR-2 is also a receptor of trypsin. Since PAR-2 agonist peptide SLIGKV- $\mathrm{NH}_{2}$ and tryptase are not capable of stimulating TNF release from $\mathrm{T}$ cells, the action of trypsin on $\mathrm{T}$ cells is not likely through activation of PAR-2.

Trypsin- and thrombin-induced upregulated expression of TNF was observed in CD4+, IL-4+ or CD25+ T cells, indicating that IL-4+, and CD25+ T cells are major sources of TNF. While little information on the relationship between $\mathrm{CD} 25+\mathrm{T}$ cells and TNF is available, a study which found that the percentage of CD4(+)CD25(+) T cells were significantly high, but the percentage of FoxP3(+) cells were low in allergic rhinitis patients, and that IL-4, IL-5, and TNF levels in nasal lavage fluids were high indicates that the increased TNF release may be from $\mathrm{CD} 4(+) \mathrm{CD} 25(+)$, nonregulatory $\mathrm{T}$ cells [23]. We believe that the current study is the first work that demonstrates coexpression of CD25 and TNF in the subtype of CD4(+) T cells. Similarly, we clearly found that IL-4+ T cells express enhanced TNF, though little information on coexpression of IL-4 and TNF in T cells is available. This finding implicates that trypsin and thrombin may be involved in the inflammation through induction of TNF release from IL-4+ or CD25+ T cells. It was demonstrated that nickel-specific CD4+ T cell lines [24] and Th17 cells [25] corelease IL-17 and TNF, but trypsin- and thrombin-induced TNF release appears not from IL-17+ T cells as TNF expression in IL-17+ $\mathrm{T}$ cells was not upregulated by these two proteinases.

MAPK/ERK pathway is the signaling pathway that is most likely involved in the thrombin- and trypsin-induced TNF release from highly purified T cells, as PD98059, an inhibitor of MAPK/ERK pathway, almost completely blocked thrombin- and trypsin-provoked phophorylation of ERK and TNF release. While little information on signaling pathways associated with PAR-1 signaling in purified T cells is available, the previous reports that PAR-1 agonists activated MAPK/ERK and p38 MAPK signaling pathways in dermal [26] and cardiac fibroblasts [27] may support our current observation that MAPK/ERK pathway is the signaling pathway that is most likely involved in the thrombinand trypsin-induced TNF release. In addition, PI3K/Akt signaling pathway seems also to be involved in thrombin and trypsin induced TNF secretion, as LY294002 an inhibitor of PI3K/Akt signaling pathway partially diminished thrombin and trypsin induced TNF secretion and completely abolished thrombin and trypsin provoked phosphorylation of Akt. This finding is in the same line with the report, which showed that thrombin stimulated enhance PI3K activity in hamster 


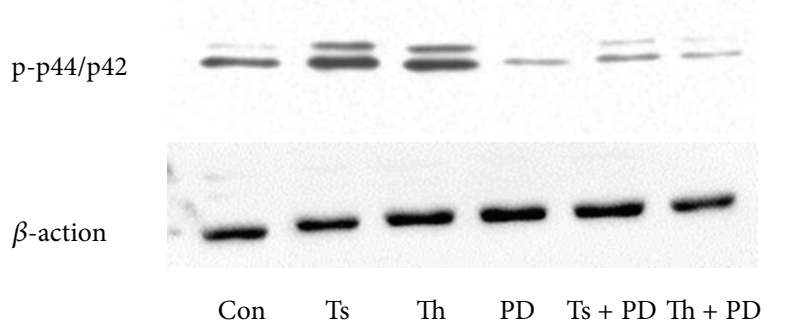

(a)

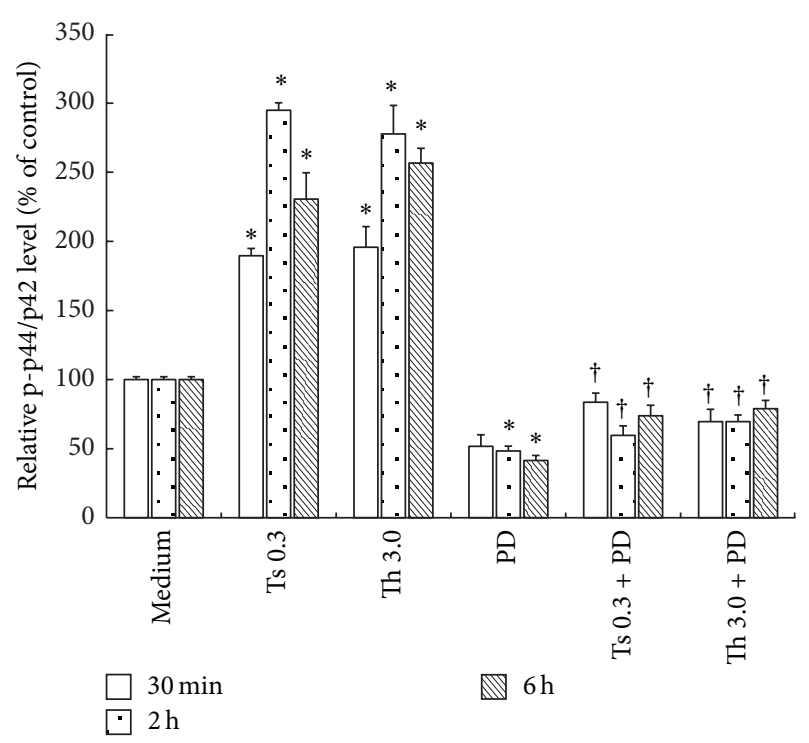

(b)

FIGURE 5: Western blot analysis of influence of PD98059 on thrombin- and trypsin-induced phosphorylation of ERK in purified T cells. PD98059 (PD, $50 \mu \mathrm{M}$ ) was preincubated with T cells at $37^{\circ} \mathrm{C}$ for $30 \mathrm{~min}$ before $3.0 \mu \mathrm{g} / \mathrm{mL}$ of thrombin and $0.3 \mu \mathrm{g} / \mathrm{mL}$ of trypsin being added for $30 \mathrm{~min}$ and 2 and $6 \mathrm{~h}$. (a) Cells were treated with thrombin and trypsin for $2 \mathrm{~h}$. (b) The relative levels of phosphoERK1/2 were expressed as the ratio to $\beta$-actin, an internal control (house keeping protein). The values shown are mean \pm SD for four separate experiments. ${ }^{*} P<0.05$ compared with the response to medium alone. ${ }^{\dagger} P<0.05$ compared with the response to the corresponding proteinase alone.

embryonic fibroblasts [28], but different from our previous report, which showed that thrombin did not enhanced PI3K activity in human dermal fibroblasts [29]. The discrepancy between these studies may be due to the difference in cell origin and species.

TNF is a member of a growing family of peptide mediators comprising at least 19 cytokines, including lymphotoxin$\alpha$, Fas ligand, and CD40 ligand. The family is now considered as central mediators of a broad range of biological activities in protective immune responses against a variety of infectious pathogens. On the other hand, TNF also exerts host-damaging effects in sepsis and autoimmune disease $[30,31]$. These findings indicate that TNF is one of key

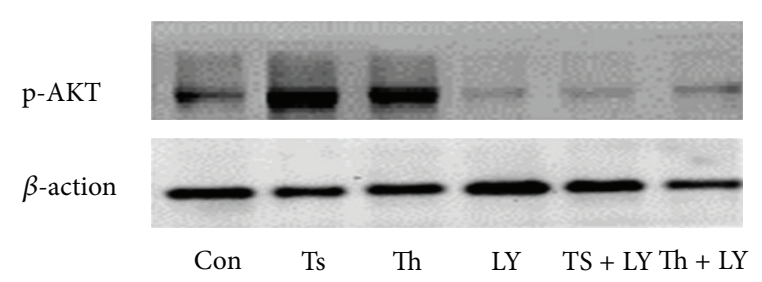

(a)

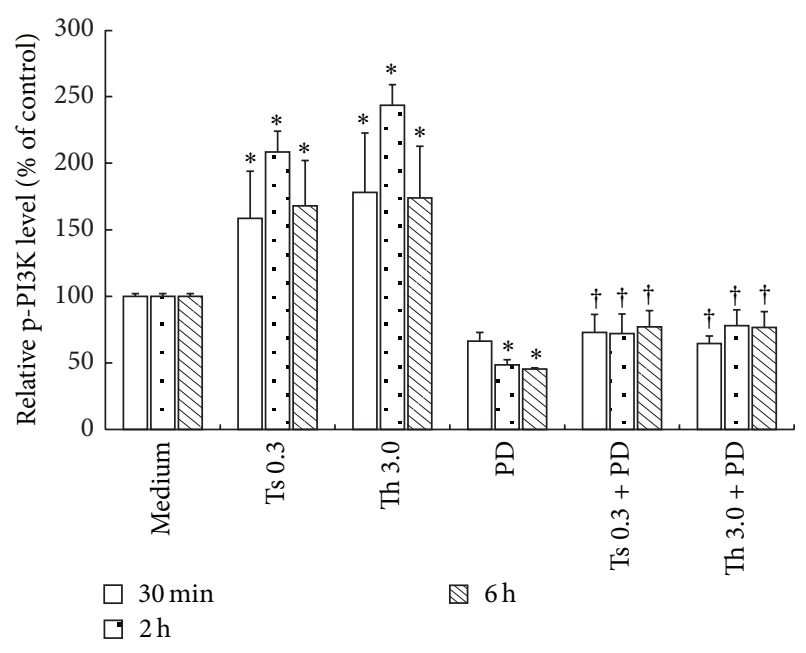

(b)

FIGURE 6: Western blot analysis of influence of LY294002 on thrombin- and trypsin-induced phosphorylation of AKT in purified T cells. LY294002 (LY, $20 \mu \mathrm{M}$ ) was preincubated with T cells at $37^{\circ} \mathrm{C}$ for $30 \mathrm{~min}$ before $3.0 \mu \mathrm{g} / \mathrm{mL}$ of thrombin and $0.3 \mu \mathrm{g} / \mathrm{mL}$ of trypsin being added for $0.5,2$, and $6 \mathrm{~h}$. (a) Cells were treated with thrombin and trypsin for $2 \mathrm{~h}$. (b) The relative levels of phosphoAkt were expressed as the ratio to $\beta$-actin, an internal control (housekeeping protein). The values shown are mean \pm SD for four separate experiments. ${ }^{*} P<0.05$ compared with the response to medium alone. ${ }^{\dagger} P<0.05$ compared with the response to the corresponding proteinase alone.

mediators of inflammation; therefore, our current study is of importance in understanding TNF-related inflammation and the mechanism of proteinase-induced cytokine production in T cells.

\section{Conclusions}

In conclusion, it is discovered in the present study that serine proteinases thrombin and trypsin are potent stimuli of TNF secretion from highly purified T cells. Their actions on T cells depend on their enzymatic activities and are likely through activation of PAR-1. Stimulation of TNF secretion from T cells by serine proteinases further proved that these proteinases are actively involved in the pathogenesis of inflammation and regulation of immune response in man. 


\section{Acknowledgments}

This project was sponsored by the Grants from the National Natural Science Foundation of China (nos. 30972714, 30972822, 81001329, 81172836, 81030054, and 81273274) and a project funded by the Priority Academic Program Development of Jiangsu Higher Education Institutions.

\section{References}

[1] S. R. Coughlin, "Thrombin signalling and protease-activated receptors," Nature, vol. 407, no. 6801, pp. 258-264, 2000.

[2] T.-K. H. Vu, D. T. Hung, V. I. Wheaton, and S. R. Coughlin, "Molecular cloning of a functional thrombin receptor reveals a novel proteolytic mechanism of receptor activation," Cell, vol. 64, no. 6, pp. 1057-1068, 1991.

[3] M. L. Kahn, Y.-W. Zheng, W. Huang et al., "A dual thrombin receptor system for platelet activation," Nature, vol. 394, no. 6694, pp. 690-694, 1998.

[4] H. Ishihara, A. J. Connolly, D. Zeng et al., "Protease-activated receptor 3 is a second thrombin receptor in humans," Nature, vol. 386, no. 6624, pp. 502-506, 1997.

[5] W.-F. Xu, H. Andersen, T. E. Whitmore et al., "Cloning and characterization of human protease-activated receptor 4," Proceedings of the National Academy of Sciences of the United States of America, vol. 95, no. 12, pp. 6642-6646, 1998.

[6] M. Molino, E. S. Barnathan, R. Numerof et al., "Interactions of mast cell tryptase with thrombin receptors and PAR-2," Journal of Biological Chemistry, vol. 272, no. 7, pp. 4043-4049, 1997.

[7] M. Steinhoff, C. U. Corvera, M. S. Thoma et al., "Proteinaseactivated receptor-2 in human skin: tissue distribution and activation of keratinocytes by mast cell tryptase," Experimental Dermatology, vol. 8, no. 4, pp. 282-294, 1999.

[8] A. Uehara, K. Muramoto, H. Takada, and S. Sugawara, "Neutrophil serine proteinases activate human nonepithelial cells to produce inflammatory cytokines through protease-activated receptor 2," Journal of Immunology, vol. 170, no. 11, pp. 56905696, 2003.

[9] G. Sun, M. A. Stacey, M. Schmidt, L. Mori, and S. Mattoli, "Interaction of mite allergens Der $\mathrm{p} 3$ and Der $\mathrm{p} 9$ with proteaseactivated receptor-2 expressed by lung epithelial cells," Journal of Immunology, vol. 167, no. 2, pp. 1014-1021, 2001.

[10] S. Verrall, M. Ishii, M. Chen, L. Wang, T. Tram, and S. R. Coughlin, "The thrombin receptor second cytoplasmic loop confers coupling to $\mathrm{G}(\mathrm{q})$ - like $\mathrm{G}$ proteins in chimeric receptors: additional evidence for a common transmembrane signaling and G protein coupling mechanism in G protein- coupled receptors," Journal of Biological Chemistry, vol. 272, no. 11, pp. 6898-6902, 1997.

[11] L. Hou, G. L. Howells, S. Kapas, and M. G. Macey, "The protease-activated receptors and their cellular expression and function in blood-related cells," British Journal of Haematology, vol. 101, no. 1, pp. 1-9, 1998.

[12] T. Li and S. He, "Induction of IL-6 release from human T cells by PAR-1 and PAR-2 agonists," Immunology and Cell Biology, vol. 84, no. 5, pp. 461-466, 2006.

[13] A. Tordai, J. W. Fenton II, T. Andersen, and E. W. Gelfand, "Functional thrombin receptors on human T lymphoblastoid cells," Journal of Immunology, vol. 150, no. 11, pp. 4876-4886, 1993.
[14] B. Mari, V. Imbert, N. Belhacene et al., "Thrombin and thrombin receptor agonist peptide induce early events of T cell activation and synergize with TCR cross-linking for CD69 expression and interleukin 2 production," Journal of Biological Chemistry, vol. 269, no. 11, pp. 8517-8523, 1994.

[15] P. J. Busse, T. F. Zhang, B. Schofield, S. Kilaru, S. Patil, and X.-M. Li, "Decrease in airway mucous gene expression caused by treatment with anti-tumor necrosis factor alpha in a murine model of allergic asthma," Annals of Allergy, Asthma \& Immunology, vol. 103, no. 4, pp. 295-303, 2009.

[16] M. Heyman and J. F. Desjeux, "Cytokine-induced alteration of the epithelial barrier to food antigens in disease," Annals of the New York Academy of Sciences, vol. 915, pp. 304-311, 2000.

[17] A. Leonardi, "The central role of conjunctival mast cells in the pathogenesis of ocular allergy," Current Allergy and Asthma Reports, vol. 2, no. 4, pp. 325-331, 2002.

[18] C. Vestergaard, C. Johansen, U. Christensen, H. Just, T. Hohwy, and M. Deleuran, "TARC augments TNF- $\alpha$-induced CTACK production in keratinocytes," Experimental Dermatology, vol. 13, no. 9, pp. 551-557, 2004.

[19] S. Waserman, J. Dolovich, M. Conway, and J. S. Marshall, "TNFalpha dysregulation in asthma: relationship to ongoing corticosteroidtherapy," Canadian Respiratory Journal, vol. 7, pp. 229-237, 2000.

[20] P. S. Thomas, "Tumour necrosis factor- $\alpha$ : the role of this multifunctional cytokine in asthma," Immunology and Cell Biology, vol. 79, no. 2, pp. 132-140, 2001.

[21] M. D. Rand, J. B. Lock, C. van't Veer, D. P. Gaffney, and K. G. Mann, "Blood clotting in minimally altered whole blood," Blood, vol. 88, no. 9, pp. 3432-3445, 1996.

[22] H.-S. Ahn, C. Foster, G. Boykow, A. Stamford, M. Manna, and M. Graziano, "Inhibition of cellular action of thrombin by N3-cyclopropyl-7-\{[4-(1- methylethyl)phenyl]methyl $\}-7 \mathrm{H}-$ pyrrolo[3,2-f] quinazoline-1,3-diamine (SCH 79797), a nonpeptide thrombin receptor antagonist," Biochemical Pharmacology, vol. 60 , no. 10, pp. 1425-1434, 2000.

[23] S. Genc, H. Eroglu, U. C. Kucuksezer et al., "The decreased $\mathrm{CD} 4+\mathrm{CD} 25+$ FoxP3+ T cells in nonstimulated allergic rhinitis patients sensitized to house dust mites," Journal of Asthma, vol. 49, no. 6, pp. 569-574, 2012.

[24] C. Albanesi, A. Cavani, and G. Girolomoni, "IL-17 is produced by nickel-specific T lymphocytes and regulates ICAM-1 expression and chemokine production in human keratinocytes: synergistic or antagonist effects with IFN- $\gamma$ and TNF- $\alpha$," Journal of Immunology, vol. 162, no. 1, pp. 494-502, 1999.

[25] M. A. McArthur and M. B. Sztein, "Unexpected heterogeneity of multifunctional T cells in response to superantigen stimulation in humans," Clinical Immunology, vol. 146, no. 2, pp. 140-152, 2013.

[26] A. Sabri, J. Short, J. Guo, and S. F. Steinberg, "Protease-activated receptor-1-mediated DNA synthesis in cardiac fibroblast is via epidermal growth factor receptor transactivation: distinct PAR1 signaling pathways in cardiac fibroblasts and cardiomyocytes," Circulation Research, vol. 91, no. 6, pp. 532-539, 2002.

[27] Z.-M. Bian, S. G. Elner, A. Yoshida, and V. M. Elner, "Human RPE-monocyte co-culture induces chemokine gene expression through activation of MAPK and NIK cascade," Experimental Eye Research, vol. 76, no. 5, pp. 573-583, 2003.

[28] R. Goel, P. J. Phillips-Mason, A. Gardner, D. M. Raben, and J. J. Baldassare, " $\alpha$-Thrombin-mediated Phosphatidylinositol 3Kinase Activation through Release of $\mathrm{G} \beta \gamma$ Dimers from $\mathrm{G} \alpha \mathrm{q}$ 
and G $\alpha$ i2," Journal of Biological Chemistry, vol. 279, no. 8, pp. 6701-6710, 2004.

[29] L. Wang, J. Luo, Y. Fu, and S. He, "Induction of interleukin8 secretion and activation of ERK1/2, p38 MAPK signaling pathways by thrombin in dermal fibroblasts," International Journal of Biochemistry and Cell Biology, vol. 38, no. 9, pp. 15711583, 2006.

[30] R. M. Locksley, N. Killeen, and M. J. Lenardo, "The TNF and TNF receptor superfamilies: integrating mammalian biology," Cell, vol. 104, no. 4, pp. 487-501, 2001.

[31] K. Pfeffer, "Biological functions of tumor necrosis factor cytokines and their receptors," Cytokine and Growth Factor Reviews, vol. 14, no. 3-4, pp. 185-191, 2003. 


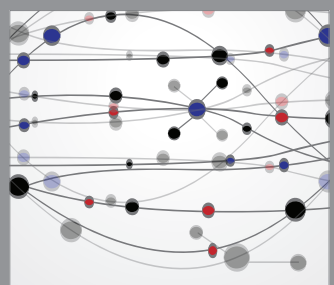

The Scientific World Journal
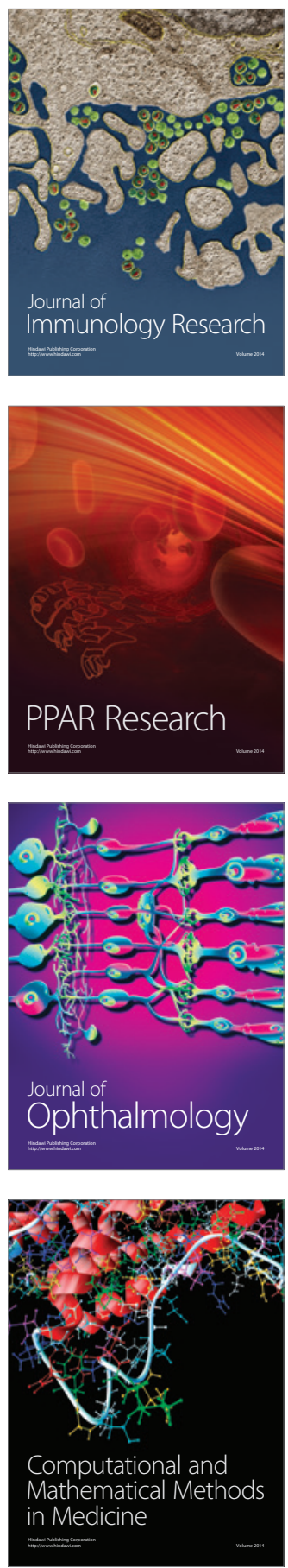

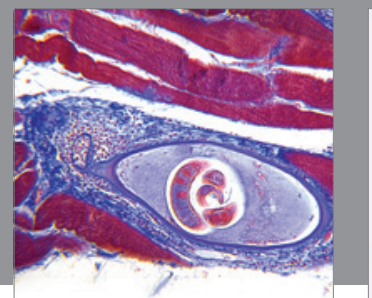

Gastroenterology

Research and Practice
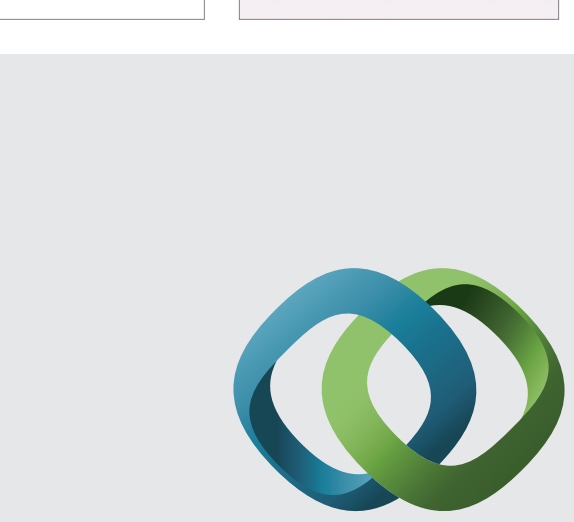

\section{Hindawi}

Submit your manuscripts at

http://www.hindawi.com
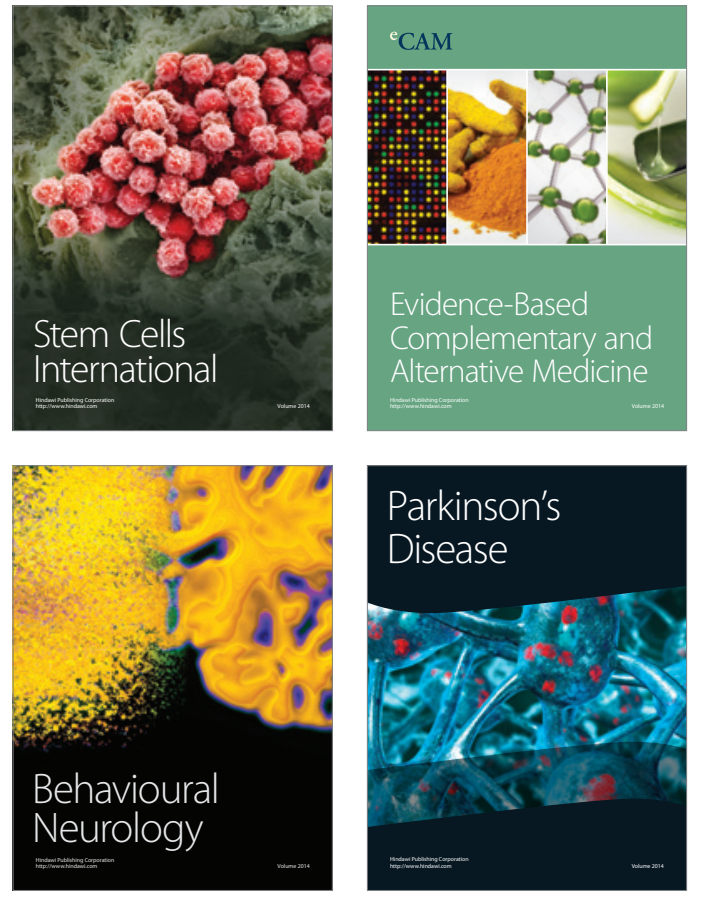
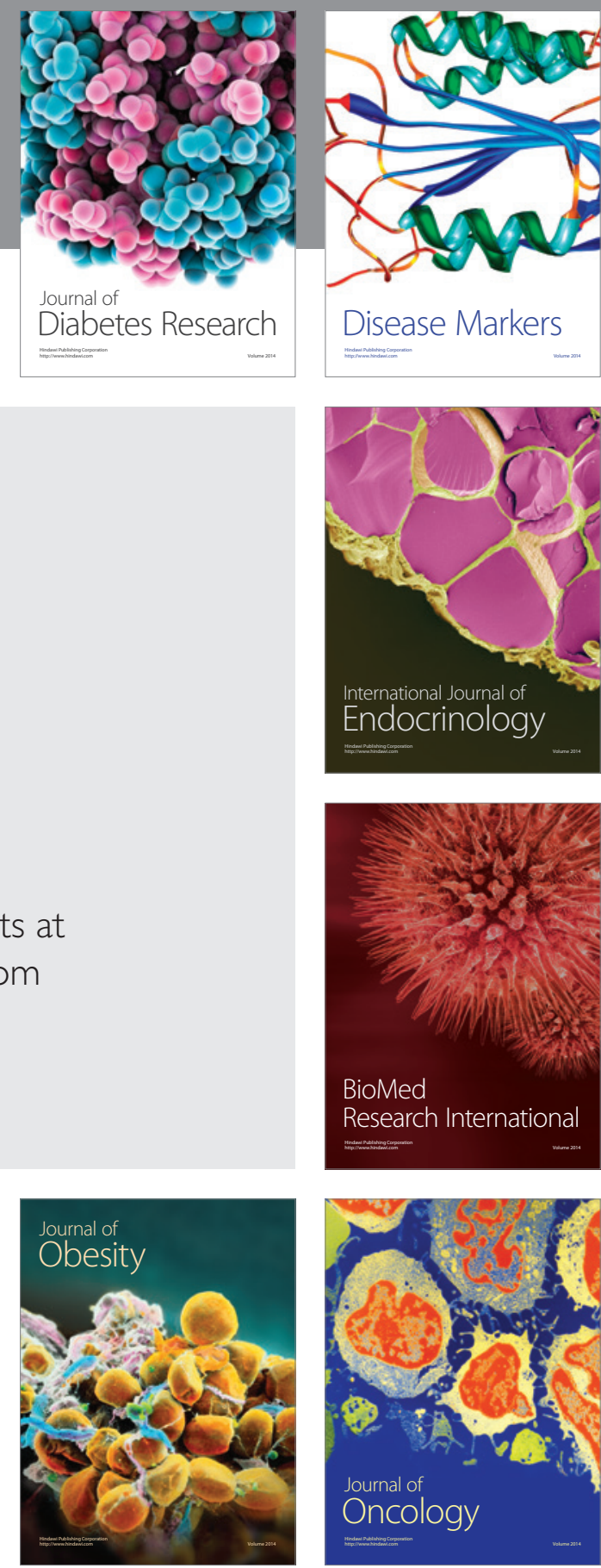

Disease Markers
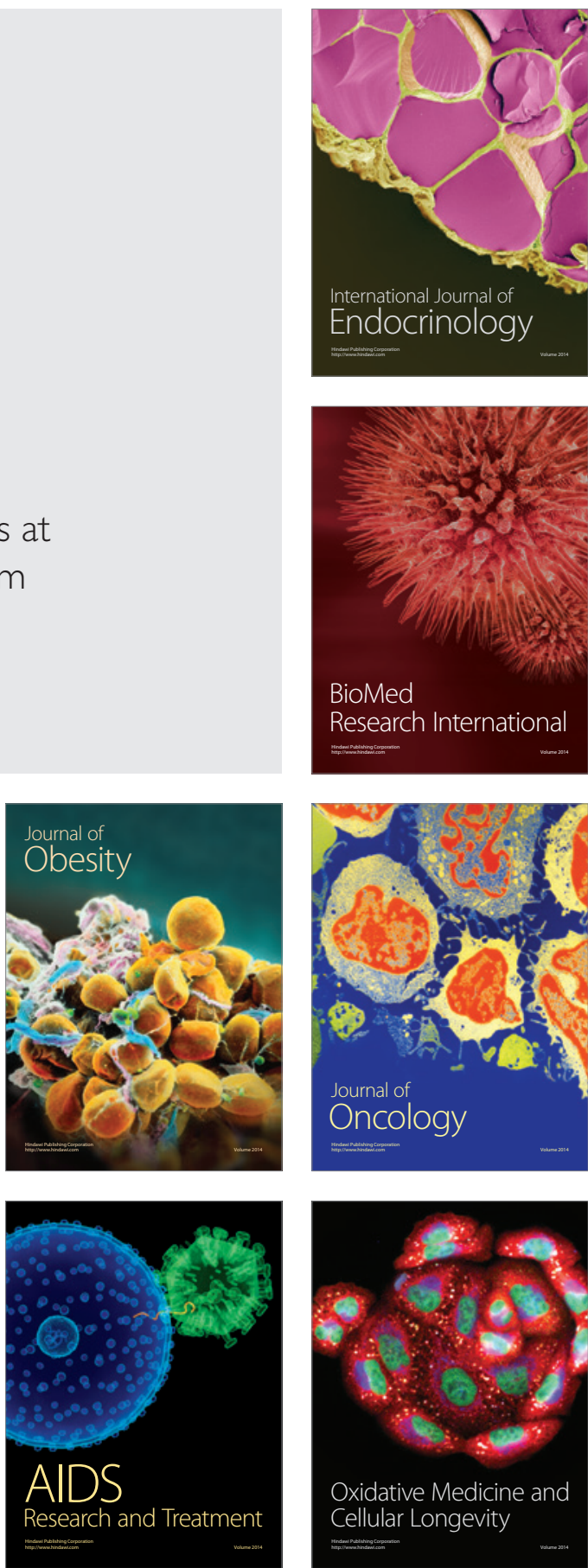